Anim. Rep. Res. Inst. ARRI, Giza-Egypt.

\title{
DIAGNOSIS OF BRUCELLOSIS IN LACTATING EWES USING MILK-ELISA
}

\author{
(With 3 Tables)
}

By

\author{
M.M. BASSIONY; K.A. ABOU GAZIA; \\ M.W. ABD AL-AZEEM* and I.G.A. IBRAHIM \\ *Department of Microbiology, Faculty of Veterinary \\ Medicine, South Valley University \\ (Received at 26/1/2010)
}

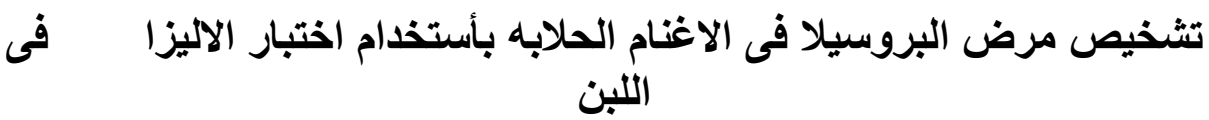

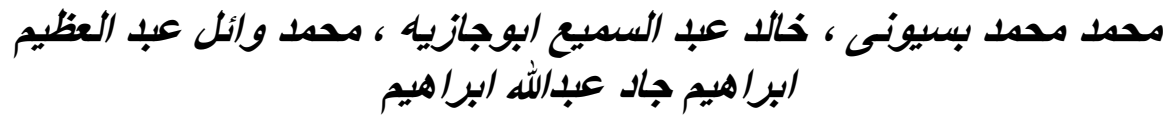

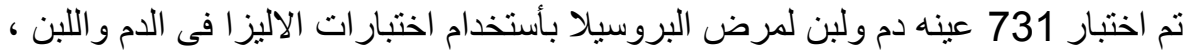

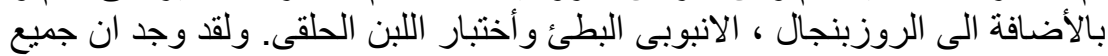

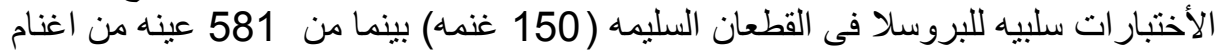

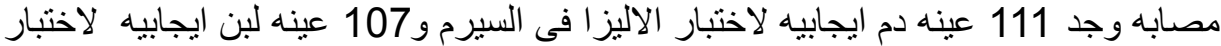

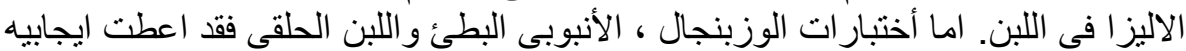

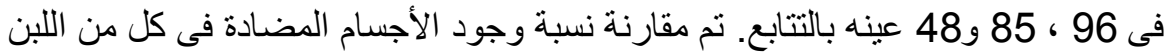

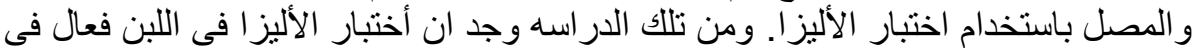
تشخيص البروسيلا فى الأغنام الحلابه.

\section{SUMMARY}

Milk and blood samples collected from 731 lactating ewes were examined for brucellosis using milk-ELISA, serum-ELISA, RBPT, SAT and MRT. Of these ewes, 150 were from brucellosis free sheep flock, which were found negative in all tests used. While, of the remaining 581 ewes, 111 were positive in serum-ELISA, 107 in milk-ELISA, 96 in RBPT, 85 in SAT, 48 in MRT and B.melitensis biovar 3 was isolated from the milk of 39 infected ewes. Of the 111 serum-ELISA positive ewes, 101 were positive and 10 were negative in milk-ELISA, whereas of the 107 milk-ELISA positive ewes, 6 ewes were negative in serumELISA. All together, 101 ewes were positive and 464 were negative in 
both the assays, while 16 ewes yield variable results. The sensitivity and positive predictive value in the infected flocks were $94.39 \%$ and $90.99 \%$ respectively. The milk-ELISA for diagnosing brucellosis seems to be an attractive alternative of serum-ELISA particularly in the lactating ewes.

Key words: Brucellosis, ELISA, ewes, milk, blood.

\section{INTRODUCTION}

Brucellosis in sheep and goats is still a major public health risk in Mediterranean and Middle East countries, although every country had begun disease control schemes (Murphy et al., 2001). The causative agent, B. melitensis, mainly affects sexually mature sheep and goats causing abortions commonly in advance stages of gestation period. The disease results in considerable economic losses to animal owners besides, restrictions in the international trade of animals and animal products. Moreover, B. melitensis is highly pathogenic to human beings and readily infects individuals following contact with infected animals or through consumption of contaminated milk or milk products (Young, 1995).

Diagnosis of brucellosis in sheep depends on the serological tests like Rose Bengal plate agglutination test (RBPT), Serum tube agglutination test (SAT), complement fixation test (CFT) and enzyme linked immunosorbent assay (ELISA); however, definitive diagnosis is done by bacteriological isolation and identification of brucellae from the infected sheep or aborted foeti.

The milk ring test (MRT) detects brucella antibodies in milk but its use in sheep and goats has not been recommended (OIE, 2000). However, milk is an excellent clinical sample which can be used either in MRT or ELISA for diagnosing brucellosis in bovines. Moreover, milk -ELISA has been preferred over MRT as the assay is highly sensitive and specific and even effective in detecting brucellosis in lactating cows earlier than MRT (Kerkhofs et al., 1990). Also, the milk-ELISA can be applied for detecting brucella antibodies in milk of lactating ewes (Biancifiori et al., 1996).

In the present study comparative study was done between milkELISA and serum-ELISA for diagnosing brucellosis in sheep. The other conventional tests including RBPT, SAT, MRT were done as well as isolation of $B$. melitensis from the milk of lactating ewes. 


\section{MATERIALS and METHODS}

A total of 731 milk and blood samples were collected from lactating ewes at different stages of lactation following lambing. Of these, 150 ewes were from the brucellosis free sheep flock used as control to ascertain specificity and sensitivity of the tests and 485 ewes from a known infected sheep flock from which $B$. melitensis has been isolated. The remaining 96 ewes belonged to different small sheep flocks of private farmers where the status of brucellosis was not known. The milk samples from all ewes were processed for the MRT on the day of their collection according to Alton et al. (1975). A positive sample was defined as one in which precipitation of the dyed antigen complex allowed clearing or partial clearing of colour from the milk or in which any clumping of dyed antigen occurred in the milk column. The milk and serum samples were stored at $-20 \mathrm{C}$ until the time of testing.

The RBPT and SAT were performed according to the standard procedure of Alton et al. (1988). Serum samples exhibiting any degree of clumping of colourd antigen in RBPT and 50\% agglutination reaction at a dilution of $1 / 40$ or above in SAT were considered positive.

All milk samples were used for isolation of brucella organisms according to Mathur (1964) and Farrell (1974). Presumptive identification of the isolates was carried out according to Alton et al. (1975).

B. melitensis biovar-3 recovered from an aborted sheep lamb was used to prepare the crude lipopolysaccharide (LPS) antigen for ELISA (Jimenez de Bagues et al., 1992). The ELISA was performed as described by Jimenez de Bagues et al. (1992) with some modifications. Briefly, the crude LPS antigen in carbonate- bicarbonate buffer $(\mathrm{pH} 9.6$; $0.05 \mathrm{M})$ was used to coat the wells of polystyrene microplates for overnight at $4 \mathrm{C}$. Following one washing with phosphate buffer saline (PBS: pH 7.2; $0.01 \mathrm{M}$ ) containing $0.05 \%$ Tween-20 (PBS-T) and blocking for $1 \mathrm{~h}$ with $5 \%$ milk (non-fat milk powder dissolved in PBS-T), diluted serum or milk samples, rabbit antisheep immunoglobulin horseradish peroxidase conjugate (Dakopats) and substrate solution $(0.4 \mathrm{mg} / \mathrm{ml}$ ortho-phenyldiamine dihydrochloride in citrate buffer, $\mathrm{pH} 5.0$; containing $0.015 \% \mathrm{H} 2 \mathrm{O} 2$ ) were serially added to wells of microplate. The colour development was stopped after $5 \mathrm{~min}$ with the addition of $100 \mathrm{ul}$ of $1 \mathrm{M}$ sulphuric acid to each well. The optical density was measured at $492 \mathrm{~nm}$. The incubation time at each step including blocking was $1 \mathrm{~h}$ at $37 \mathrm{C}$ and three washing with PBS-T 
were done by an ELISA plate washer after every incubation step. Duplicate wells with 100 ul volumes were used for each sample. The optimum concentration of crude LPS antigen to be used in the assay was determined by box titration using pooled positive and pooled negative controls. The pooled positive controls comprised serum and milk samples obtained from the brucellosis infected sheep flock from ten brucella positive lactating ewes. The negative controls were from the brucellosis free sheep flock. The serum samples were diluted1:100 and milk samples 1:20 for testing. The negative and positive controls were always included while examining the serum and milk samples. The criterion for considering a sample positive or negative was based on percent positivity $(\% \mathrm{P})$ calculated as follows:

Percent positivity $"(\% \mathrm{P})=\underline{\text { O.D. value of test sample }} \mathrm{X}$ 100

Average O.D.value of positive controls

Samples with equal or above $25 \%$ positivity were considered positive. Also the end point antibody titres were determined in all ELISA positive milk and serum samples. The specificity, sensitivity and predictive values of milk-ELISA were determined in relation to serumELISA (Tizard, 1982). The correlation of antibody titres in milk and serum as detected by milk-ELISA and serum-ELISA, respectively, was calculated by Chi-square (x2) test.

\section{RESULTS}

It is clear from the results shown in Table 1 that all milk and serum samples from 150 lactating ewes belonged to a brucellosis free sheep flock were negative in milk-ELISA (m-ELISA) as well as in serum-ELISA (s-ELISA). Hence, the specificity of both ELISA was $100 \%$ in this flock. Also, the RBPT, SAT and MRT were negative and B.melitensis could not be isolated from them. On the other hand, 107 ewes were positive in m-ELISA and 111 in s-ELISA out of 581 animals belonged to infected and unknown sheep flocks But, the PBPT, SAT and MRT detected 96, 85 and 48 ewe's positive for brucellosis, respectively.

B. melitensis biovar-3 was isolated from the milk of 39 ewes. All the culture positive ewes were also positive in m-ELISA as well as in s-ELISA, which indicated $100 \%$ sensitivity of both the assays in cultureproven cases. 
A comparison of the results of m-ELISA and s-ELISA performed on ewes from the infected sheep flocks is given in Table 2. It was observed that out of 581 ewes 101 were positive in both the assays, while $6 \mathrm{~m}$-ELISA positive ewes were negative in s-ELISA and 10 s-ELISA positive ewes were negative in m-ELISA. Amongst the 10 serum-positive-milk negative ewes s-ELISA titres in 8 ewes were between 1:100 and 1: 200 whereas 1:400 in two ewes. The sensitivity of $\mathrm{m}$-ELISA in relation to s-ELISA in a suspected or infected sheep flocks was $94.39 \%$ and the positive predictive value of the test was $90.99 \%$.

Table 3 illustrates the end point antibody titers in milk and serum samples of 101 ewes that were positive in m-ELISA as well as in $\mathrm{s}$-ELISA. The antibody titers in milk as determined by m-ELISA correlated statistically with the antibody titres in sera of ewes ( $22=45.61$; $\mathrm{r}=0.57)$.

Table 1: Serological diagnosis of brucellosis using s-ELISA, m-ELISA, RBPT, SAT, and MRT performed on 731 lactating ewes

\begin{tabular}{|c|c|c|c|ccccc|}
\hline $\begin{array}{c}\text { Sr. } \\
\text { no. }\end{array}$ & Sheep flock & $\begin{array}{c}\text { Status of } \\
\text { Brucellosis }\end{array}$ & $\begin{array}{c}\text { Number of } \\
\text { ewes tested }\end{array}$ & \multicolumn{4}{|c|}{ Number of ewes positive in } & \\
\hline 1 & $\begin{array}{c}\text { Organized } \\
\text { farm }\end{array}$ & Negative & 150 & - & - & - & - & - \\
\hline 2 & $\begin{array}{c}\text { Organized } \\
\text { farm }\end{array}$ & Infected & 485 & 95 & 92 & 86 & 77 & 44 \\
\hline 3 & $\begin{array}{c}\text { Private } \\
\text { farm }\end{array}$ & Not known & 96 & 16 & 15 & 10 & 8 & 4 \\
\hline Total & & 731 & 111 & 107 & 96 & 85 & 48 \\
\hline
\end{tabular}

Samples Serum-ELISA

Milk-ELISA

Positive Negative Sensitivity (\%) Positive predictive value (\%)

$\begin{array}{llll}\text { Positive } & 111 & 101 & 10\end{array}$

Negative $\quad 470 \quad 6 \quad 464$ 


$\begin{array}{llllll}\text { Total } & 581 & 107 & 474 & 94.39 & 90.99\end{array}$

Table 2: Comparison between serum-ELISA and milk-ELISA for samples from infected sheep flocks

Table 3: Comparison of end point antibody titres in milk and serum samples of 101 milk-ELISA and serum-ELISA positive ewes

\begin{tabular}{|c|c|c|c|c|c|c|c|c|}
\hline \multirow{2}{*}{$\begin{array}{l}\text { Serum-ELISA titres } \\
\text { Total }\end{array}$} & \multicolumn{7}{|c|}{ milk-ELISA titres } & \\
\hline & $<1: 40$ & $1: 40$ & $1: 80$ & $1: 160$ & $1: 320$ & $1: 640$ & $1: 1280$ & \\
\hline$<1: 200$ & & & & & & & & Nil \\
\hline 1:200 & & 3 & 2 & & & & & 5 \\
\hline $1: 400$ & & & 7 & 2 & & & & 9 \\
\hline 1:800 & & & 14 & 18 & 5 & & & 37 \\
\hline $1: 1600$ & & & 3 & 15 & 19 & & & 37 \\
\hline $1: 3200$ & & & & 3 & 4 & 3 & & 10 \\
\hline$>1: 6400$ & & & & & & 1 & 2 & 3 \\
\hline Total & Nil & 3 & 26 & 38 & 28 & 4 & 2 & 101 \\
\hline
\end{tabular}

\section{DISCUSSION}

Diagnosis of brucellosis in small ruminants largely depends upon serological methods, as isolation of the causative agent is difficult, cumbersome and insensitive method. The milk and / or serum from animals are conventionally used as clinical samples for serological diagnosis of brucellosis in animals and ELISA has been preferred over many other serological methods (Nielsen et al., 1995; Saravi et al., 1995; Jacques et al., 1998; Samartino et al., 1999). In addition, ELISA has been shown to be equally effective in determining brucella antibody in milk and serum (Heck et al., 1980; Smith et al., 1989; Nielsen et al., 1996).

The milk is an excellent clinical sample for ELISA or milk ring test for diagnosing brucellosis in bovines. The milk from sheep and 
goats has also been conventionally used in MRT for the purposes of diagnosis of brucellosis however MRT is not reliable in sheep and goats (Alton, 1987; OIE, 2000). Little information is available on the value of milk-ELISA for the diagnosis of brucellosis in sheep (Biancifiori et al., 1996; Garin-Bastuji et al., 1998). The present study was conducted to assess and compare the brucella antibody levels in milk and blood so that a serological status of lactating ewes could be ascertained for diagnostic purposes. To achieve this goal the milk and blood from the ewes were collected simultaneously and then tested by ELISA. The crude preparation of LPS antigen obtained from B. melitensis biovar-3 was used in ELISA in the present study. The crude preparation of LPS from B. melitensis has been shown to contain $40 \%$ LPS and $42 \%$ protein (Alonso-Urmeneta et al., 1998) and such preparation also contains other serologically relevant components, the outer membrane proteins (Omp31 and Omp25). This could increase the possibility of detection of antibody responses against outer membrane proteins including Omp31 and Omp25 in addition to LPS, which eventually would produce positive effect on the performance of the assay. Nevertheless, the use of crude LPS in ELISA has been suggested to be a practical choice (Jimenez de Bagues et al., 1992; Alonso-Urmeneta et al., 1998) as the antigen is technically simple to obtain. However, in the present study it was not possible to ascertain that antibodies to Omp31 and Omp25 were present in each sample examined. Cassataro et al. (2004) mentioned that chances of detection of these antibodies, if present, by the crude LPS-based ELISA were very high as about half of the amounts of crude LPS antigen preparation was the outer membrane proteins.

Examination of blood and milk samples by ELISA from 150 lactating ewes belonging to a sheep flock free from brucellosis revealed that all the animals were negative for brucellosis. These observations suggested that both milk-ELISA and serum-ELISA were $100 \%$ specific and correlated well in examining a brucellosis free sheep flock. These results are in confirmatory with the findings of Biancifiori et al. (1996), where in milk-ELISA has been shown to be $100 \%$ specific in brucellosis free flocks. In brucellosis infected sheep flocks a correlation between milk-ELISA and serum- ELISA was observed as of the 581 brucellosis suspected ewes, 101 were detected positive and 464 negative in both the assays. Only 16 ewes gave variable results, of these, 6 were positive in milk-ELISA and 10 in serum-ELISA independently. No specific reason could be attributed to the 6 cases which were milk-ELISA positive only because almost all amounts of $\operatorname{IgG}$ in milk is derived from serum by a 
selective transfer of IgG from the circulating blood to milk (Norcross, 1982). However, a local antibody synthesis against an antigenic stimulation of the mammary gland and then secretion of the reactive antibodies in the milk of few ewes cannot be ruled out. In 10 ewes that were positive in serum-ELISA only the concentration of brucella specific antibody in milk seemed below the detection limit of milkELISA. This very low amount of brucella IgG in the milk could possibly be either due to low levels of brucella antibodies in sera of these ewes or hindrance in transport of IgG from blood to milk. The first possibility appeared to be the probable reason in 8 ewes as these had antibody titres below 1:200 in their sera in serum-ELISA. While in 2 ewes that had serum antibody titres above 1:200 the hindrance in transport of IgG from blood to milk seemed likely because an acute inflammatory condition has been shown to severely impair the normal function of the mammary gland in respect of selective transfer of $\mathrm{IgG}$ from blood to milk at least for $24 \mathrm{~h}$ (Mackenzie and Lascelles, 1968).

Such an acute condition could be expected in few ewes at the time point of collection of samples in a population of ewes examined.

A correlation in antibody levels in blood and milk of lactating ewes is very much expected because a certain proportion of $\mathrm{IgG}$ is selectively transferred from blood to milk in a normal lactating animal (Watson and Lascelles, 1973; Norcross, 1982). Since specific antibody levels in blood of an infected animal depend on the stage and duration of infection, it would be of interest to examine the specific antibody levels in the milk and serum of the same animal to find out a correlation which could be used as a criterion for diagnosing the disease simply on the basis of testing a milk sample alone. The brucella antibody levels in milk and serum of lactating ewes were determined by end point antibody titration by ELISA. A correlation was found to exist in antibody levels in milk and serum. Apparently, the antibody levels were about 5-10 times higher in serum than milk in majority of the ewes tested (Table 3). Based on these observations, it is reasonable to conclude that the milk antibody levels reflect the serological status of the animal and can be safely considered for deciding an animal serologically positive or negative for brucellosis.

The milk-ELISA developed by Biancifiori et al. (1996) for sheep brucellosis was shown to be less sensitive than RBPTand CFTand even failed to detect one culture positive ewe out of the 13 ewes, which were excreting brucella organisms in their milk. They also reported that milkELISA was not sensitive enough in detecting infected ewes by random 
testing of milk from a sheep flock with high disease prevalence and poorly viable in screening pooled samples in milking flocks. While the results of the present study were otherwise which clearly showed that milk-ELISA was more sensitive than RBPTand as efficient as serumELISA in detecting infected ewes. Nonetheless, the milk-ELISA was $100 \%$ effective in detecting all the 39 ewes that were excreting brucella organisms in their milk. The performance of milk-ELISA on pooled milk samples was not evaluated in the present study; however, it is an interesting area which is needed to be explored.

Testing of milk has several merits over testing of sera. Obtaining of milk from an animal is easy, simple, inexpensive and very much animal-owner friendly. The animal owners commonly cooperate in collection of milk from their animals because the sample is obtained by non-invasive manner. Nevertheless, the sample condition like colostrum, clotted milk, frozen or stored milk or milk like a cream from a drying animal does not interfere in testing by ELISA (Gupta et al., 2002). However, ewes which are not in lactation escape testing.

In conclusion, the results of present study clearly showed that the milk-ELISA is comparable to serum- ELISA and milk-ELISA could replace serum-ELISA in lactating ewes for establishing serological status for brucellosis for diagnostic purposes but serum-ELISA is still needed for non-lactating females and males sheep.

\section{REFERENCES}

Alonso-Urmeneta, B.; Marin, C.; Aragon, V.; Blasco, J.M.; Diaz, R. and Moriyon, I. (1998): Evaluation of lipopolysaccharides and polysaccharides of different epitopic structures in the indirect enzyme linked immunosorbent assay for diagnosis of brucellosis in small ruminants and cattle. Clin. Diagn. Lab. Immunol. 5: 749-754.

Alton, G.G. (1987): Control of Brucella melitensis infection in sheep and goats-a review. Trop. Anim. Health Prod. 19: 65-74.

Alton, G.G.; Jones, L.M. and Pietz, D.E. (1975): Laboratory Techniques in Brucellosis, second ed. WHO Monograph Series No. 55, Geneva.

Alton, G.G.; Jones, L.M.; Angus, R.D. and Verger, J.M., (1988): Techniques for Brucellosis Laboratory. Inst. Nat. De La Rec. Agronomique, INRA, Paris 
Biancifiori, F.; Nannini, D.; Di Matteo, A. and Belfiore, P. (1996): Assessment of an indirect ELISA in milk for the diagnosis of ovine brucellosis. Comp. Immunol. Microbiol. Infect. Dis. 19: $17-24$.

Cassataro, J.; Pasquevich, K.; Bruno, L.; Wallach, J.C.; Fossati, C.A. and Baldi, P.C. (2004): Antibody reactivity to Omp31 from Brucella melitensis in human and animal infections by smooth and rough brucellae. Clin. Diagn. Lab. Immunol. 11: 111-114.

Farrell, I.D. (1974): The development of a new selective medium for the isolation of Brucella abortus from contaminated sources. Res. Vet. Sci. 16: 280-286.

Garin-Bastuji, B.; Blasco, J.M.; Grayon, M. and Verger, J.M. (1998): Brucella melitensis infection in sheep: present and future. Vet. Res. 29: 255-274.

Gupta, V.K.; Rana, R. and Vihan, V.S. (2002): Dot ELISA for detection of Brucella melitensis antibodies in goats. Ind.J.Anim.Sci. 72(3): 237-239.

Heck, F.C.; Williams, J.D.; Pruett, J.; Sanders, R. and Zink, D.L. (1980): Enzyme linked immunosorbent assay for detecting antibodies to Brucella abortus in bovine milk and serum. Am. J. Vet. Res. 41: 2082-2084.

Jacques, I.; Bernardin, V.O. and Durby, G. (1998): Efficacy of ELISA compared to conventional tests (RBPT and CFT) for the diagnosis of Brucella melitentsis infection in sheep. Vet. Microbiol. 64: 61-73.

Jimenez de Bagues, M.P.; Marin, C.M.; Blasco, J.M.; Moriyon, I. and Gamazo, C. (1992): An ELISA with lipopolysaccharide antigen for the diagnosis of B. melitensis infection in sheep and for the evaluation of serological response following subcutaneous or conjunctival B. melitensis strain Rev 1 vaccination. Vet. Microbiol. 30: 233-241.

Kerkhofs, P.; Botton, Y.; Thiange, P.; Dekeyser, P. and Limet, J.N. (1990): Diagnosis of bovine brucellosis by enzyme immunoassay of milk. Vet. Microbiol. 24, 73-80. 310 P. Chand et al. / Veterinary Microbiology 108 (2005) 305-311

Mackenzie, D.D.S. and Lascelles, A.K. (1968): The transfer of [131I]labelled immunoglobulins and serum albumin from blood into milk of lactating ewes. Aust. J. Exp. Biol. Med. Sci. 46: 285-294. 
Mathur, T.N. (1964): Brucella strains isolated from cows buffaloes, goats, sheep and human beings at Karnal: their significance with regard to the epidemiology of brucellosis. Ind. J. Med. Res. 52: 1231-1240.

Murphy, E.A.; Parent, M.; Sathiyasselan, J.; Jiang, X. and Baldwin, C.L. (2002): Immune control of Brucella abortus 2308 infection in BALB/c mice. EFMS Immunol. Med. Microbiol. 32: 85-88.

Nielsen, K.H.; Kelly, L.; Gall, D.; Nicoletti, P. and Kelly, W. (1995): Improved competitive enzyme immunoassay for the diagnosis of bovine brucellosis. Vet. Immonol. Immunopathol. 46: 285-291.

Norcross, N.L. (1982): Secretion and composition of colostrum and milk. J. Am. Vet. Med. Assoc. 181: 1057-1060.

OIE, (2000): Caprine and ovine brucellosis (excluding Brucella ovis infection). In: Manual of Standards for Diagnostic Tests and Vaccines, fourth ed. Office International des Epizooties, Paris, France, pp. 475-489.

Saravi, M.A.; Wright, P.F.; Gregoret, R.J. and Gall, D.E.J. (1995): Comparative performance of the enzyme linked immunosorbent assay (ELISA) and conventional assays in the diagnosis of bovine brucellosis in Argentina. Vet. Immonol. Immunopathol. 47: 93-99.

Samartino, L.; Gall, D.; Gregoret, R. and Nielesn, K. (1999): Validation of enzyme-linked immunosorbent assay for the diagnosis of bovine brucellosis. Vet. Microbiol. 70: 193-200.

Smith, B.P.; Oliver, D.G. and Singh, P. (1989): Detection of Salmonella dublin mammary gland infection in carrier cows using an enzyme linked immunosorbent assay for antibody in milk and serum. Am. J. Vet. Res. 50: 1352-1360.

Tizard, I. (1982): Serological assays. J. Am. Vet. Med. Assoc. 181, 1162-1165.Young, E.J., 1995: An overview of human brucellosis. Clin. Infect. Dis. 21: 283-290.

Watson, D.L. and Lascelles, A.K. (1973): Mechanism of transfer of immunoglobulins into mammary gland of ewes. Aust. J. Exp. Biol. Med. Sci. 51: 247-254. 
Assiut Vet. Med. J. Vol. 56 No. 125 April 2010 